\title{
Transnational Mobility of Academics: Some Academic Impacts
}

Sintayehu Kassaye Alemu ${ }^{1}$

$\approx \quad$ This paper deals with the short- and long-term transnational mobility of academics and some of its impacts, an issue not well addressed in the literature. Through a qualitative literature review, the paper aims to answer the question: What are some of the academic impacts of the transnational mobility of academics? Transnational academic mobility is academic travel across borders of states and is one aspect of the new internationalisation of higher education. It is presented in terms of the roles of academics in teaching-learning experiences as well as knowledge production and transfer. The discussion extends to unpacking the impacts of the transnational mobility of academics in relation to institutional affiliation and academic status and profile. These issues are emphasised because they are major academic issues of transnational academics. From these perspectives, mobile academics have gained benefits but sometimes also faced challenges.

Keywords: transnational mobility, academics, impacts, knowledge production and transfer, academic status and profile, transnational identity capital 


\section{Transnacionalna mobilnost akademikov: nekateri akademski učinki}

Sintayehu Kassaye Alemu

$\propto$ Članek obravnava kratkoročno in dolgoročno transnacionalno mobilnost akademikov in nekatere njene učinke; ta tematika v literaturi ni obravnavava $\mathrm{v}$ zadostni meri. S kvalitativnim pregledom literature želimo v članku odgovoriti na vprašanje, kateri so nekateri akademski učinki transnacionalne mobilnosti akademikov. To je prehajanje akademikov prek državnih meja in je eden izmed vidikov nove internacionalizacije visokošolskega izobraževanja. Predstavljena je z vidika vloge akademikov pri poučevanju in pridobivanju učnih izkušenj ter pri ustvarjanju in prenosu znanja. Razprava se razširja na prepoznavanje učinkov transnacionalne mobilnosti akademikov na institucionalno pripadnost, akademski status in profil, kar so osrednja akademska vprašanja, s katerimi se spoprijemajo transnacionalni akademiki. S teh vidikov je mobilnost akademikom koristila, občasno pa so se srečevali tudi $\mathrm{z}$ izzivi.

Ključne besede: transnacionalna mobilnost, akademiki, učinki, ustvarjanje in prenos znanja, akademski status in profil, transnacionalni identitetni kapital 


\section{Introduction}

The aim of this article emanates from the following question: What are some of the academic impacts of the transnational mobility of academics? The objective is therefore to discuss some of the academic impacts of the internationalisation of the academic profession, as represented by academic scholars. On the basis of a qualitative review of the related literature, the paper focuses on such issues as transnational knowledge production and transfer, transnational identity or learning experiences, institutional affiliations, and academic status and profile. These issues are emphasised because they represent the major academic activities and relations of transnational academics and their institutions.

The article is constituted by such concepts as the academic profession, academics, internationalisation, globalisation and transnational mobility, all of which require brief elucidation. According to Kehm and Teichler (2013), the academic profession, represented by academics, is an altruistic academic occupation that has strong intellectual content, often leading to distinctive academic outcomes. Moreover, knowledge specialty with high academic qualification, acquired through a high level of practical and intellectual skills coupled with a high standard of ethical behaviour, is an important characteristic of the academic profession. The academic profession is a holding company of academic disciplines. The Merriam-Webster dictionary defines an academic as a person who is a teacher in a college or university; a member of an institution of learning who has acquired formal education especially at a college or university. Vabø (2007) defines modern academic professionals as scientific employees at universities and university colleges.

Although the internationalisation of higher education is understood differently by different people and has both inward and outward dimensions, Jane Knight (2004) defines it as an inward "process of integrating an international, intercultural, or global dimension into the purpose, functions, or delivery of post-secondary education". However, this definition does not explain the outward dimension of the internationalisation of higher education. In terms of its dynamic transformational dimensions of scope, role, actors, concept, activities, aims and rationales, the internationalisation of higher education denotes both inward and outward mobility of people, programmes and providers across institutions, departments, sectors, nations, regions and the globe. The mobility of people, programmes and providers involves students, teachers, institutions, governments, organisations and agencies as actors (Alemu, 2016). From this perspective, the internationalisation of higher education is also understood as “... an approach oriented strategic process of cross-border (departmental, 
sector, local, national, institutional, regional, international) mobility, integrity, and interaction of academic people, program, and/or institutions of tertiary education to achieve academic, cultural, economic, social and/or political benefits" (Alemu, 2016, p. 309). Globalisation, on the other hand, is a contested and more inclusive ideological formation and social imaginary concept. For the purposes of the present paper, it can be understood as technology-driven and borderless socioeconomic, political and cultural interconnectedness. J. Knight (1999) considers globalisation as "the flow of technology, economy, knowledge, people, value, ideas ... across borders", affecting countries differently. Her definition reads partly as follows:

Globalization is the flow of technology, economy, knowledge, people, values, ideas [...] across borders. Globalization affects each country in a different way due to a nation's individual history, traditions, culture and priorities. Internationalization of higher education is one of the ways a country responds to the impact of globalization yet, at the same time respects the individuality of the nation. (Knight, 1999, p. 14)

Mobility of academics, which is an aspect of the internationalisation of higher education, can take the form of academics (academics, researchers and students) travelling across borders of states, institutions, systems and disciplines. However, the present paper focuses on the short- and long-term transnational mobility or cross-border mobility of academics and researchers in the realm of the new internationalisation. The transnational mobility and migration of academics is frequently shaped by intellectual periphery/centre relationships rather than merely being directed by purely economic incentives. The direction of academic mobility is significantly vertical; it is from less developed HEIs/states (periphery) to developed states (centres). In other words, the mobility of academics is mainly from peripheries (less developed and furnished HEIs) to centres (well developed and furnished HEIs).

With varying degrees of involvement, most nations experience both an inflow and/or outflow of researchers and academics. In addition to personal gains, it is argued that researchers' transnational mobility provides potential benefits to higher education institutions of both countries of origin and destination (Hugo, 2009). However, there are also drawbacks. These are often recognised as consequences of the imbalances between outflows and inflows and differences in academic and social cultures. In spite of this, studies analysing the impacts of the transnational mobility of academics are rare. 
In addition to personal benefits from economic gains and academic tourism, the transnational mobility of academics has various academic and professional impacts. The impacts of the internationalisation of the academic profession, epitomised by academic scholars, can be discussed in terms of the benefits and challenges of academics in teaching-learning experiences and knowledge production, transfer and commodification. Academic mobility has facilitated collaborative knowledge production, knowledge movement and publication (Hamza, 2010; Krstic, 2012). It also results in the development of personal, professional and international experiences in teaching and research (Hamza, 2010; Sandgren et al., 1999), experiences that exceed the immediate individual, institutional and national contexts (Bedenlier \& Zawacki-Richter, 2015).

In recent decades, however, mobile academics have experienced challenges in integrating into foreign academic culture (Power, 1994; Strathern, 2000). In spite of J. Knight's (2004) assumption of "cultural integration" in her definition of internationalisation, mobile academics have continued to be marginalised as strangers, outsiders and minorities (Balasooriya et al., 2014; Kim \& Brooks, 2012; Pherali, 2012). For instance, almost all of the vignettes on mobility experiences from the project known as "University in the Knowledge Economy"2 (UNIKE - in the Initial Training Network (ITN)) confirm that cultural integration is not only difficult but also challenging, often seeming impossible. One of the UNIKE partners (who wishes to remain anonymous) observed and concluded that "foreigners are forever foreign".

Based on panellist ${ }^{3}$ responses and a literature review, Bedenlier and Zawacki-Richter (2015) categorised the perceived impacts of transnational academic mobility into individual, institutional and global levels or categories (Table 1).

2 University in the Knowledge Economy (UNIKE) was a European Commission funded PhD and post-doc research project run by six European universities (2013-2017): Aarhus University (Denmark), University of Ljubljana (Slovenia), University of Porto (Portugal), Leon Research Centre (France), Bristol University and University of Roehampton (UK). See http://unike.au.dk.

3 More than 30 panellists from 14 countries of the Western world and Asia responded. Therefore, the voice of Africa is not included. The most serious impact of the internationalisation of higher education on African academics is ethical: unequal arrangements of partnership, the commodification and commercialisation of higher education, the undermining of national academic endeavours, and international mobility that is often accompanied by a brain drain, as well as Western hegemonic perspectives, structures and research priorities. The 14 countries were the USA, the UK, the Netherlands, Australia, Portugal, Canada, Italy, Malaysia, Sri Lanka, Germany, the Republic of Korea, Japan, Ireland, and Hong Kong (Bedenlier \& Zawacki-Richter, 2015, p. 6). 
Table 1

Level-Based Perceived Impacts

\begin{tabular}{|c|c|c|}
\hline No. & Levels & Perceived impacts \\
\hline \multirow{7}{*}{1} & \multirow{7}{*}{ Individual Level } & Opportunity and need for personal development \\
\hline & & Considering the situation of foreign-born colleagues \\
\hline & & Foreign language acquisition \\
\hline & & Opportunity and need for professional development \\
\hline & & Increased workload and stress factors \\
\hline & & International reputation, promotion and tenure \\
\hline & & Establishing global academic networks/friendship (mine) \\
\hline \multirow{10}{*}{2} & \multirow{10}{*}{ Institutional level } & Presence of a more international student body \\
\hline & & Teaching international students \\
\hline & & Need for sensitive behaviour towards international students \\
\hline & & Internationalisation of the curriculum \\
\hline & & International research teams and publications \\
\hline & & International dissemination and visibility of research results \\
\hline & & Anglo-American hegemony of perspectives and structures \\
\hline & & Economic aspects and funding \\
\hline & & Forms of engagement within and beyond one's institution \\
\hline & & Institutional and individual impediments \\
\hline \multirow{9}{*}{3} & \multirow{9}{*}{ Global Level } & English as lingua franca \\
\hline & & Cooperation, interconnectedness and spread of knowledge \\
\hline & & International mobility of faculty \\
\hline & & Policy context and global developments \\
\hline & & Academic competition \\
\hline & & Expansion of perception and perspective \\
\hline & & Application of information and communication technology \\
\hline & & Heterogenisation and pluralisation \\
\hline & & Responding to future challenges \\
\hline
\end{tabular}

Note. Adapted from Bedenlier \& Zawacki-Richter, 2015, pp. 7-10.

In Table 1, individual impacts are most closely related to immediate personal experiences and perceptions, whereas the institutional level refers to impacts related to teaching, research, services and organisation. Institutional impacts are observed in the context of higher education institutions, affecting faculty members in their professional life and determining their personal involvement and engagement in the international arena. Global level impacts are partly abstract or globally obvious, and either affect academics personally 
or impact on a global and structural dimension of the academic profession. As Table 1 shows, each level has its own perceived impacts, which are multifaceted and overlapping. These impacts cover a wide range of issues, some of which directly affect academics, while others occur through the institution or in society at large, and thus have an indirect influence on the academic profession. Institutional impacts are often caused by the mobility of academics. It is therefore very difficult to establish a clear line between individual and institutional impacts; all of them are interdependent and mainly caused by the transnational mobility of academics.

\section{Knowledge Production, Transfer and Commodification}

Since the mid-1980s, partly associated with the internationalisation of the academic profession, the status of knowledge and the mode of knowledge production have altered (Hopkins, 2013; Meek, 2003). For some academics, the mobility of academics is an imperative experience that leads them to a new breakthrough and a paradigm shift in knowledge creation (Altbach, 2007). It has been suggested that researchers who show a high level of mobility are exposed to different schools of thought and may therefore be more likely to pursue new and unexplored research topics with better research productivity, efficiency and quality than immobile academics or less mobile academics (Hopkins, 2013). For example, a study report of the UK's Department for Business, Innovation and Skills (2012) confirmed that international academic mobility has the effect of contributing better research productivity, efficiency and quality. According to the report, UK academics are more mobile than those from Canada, China, France, Germany, Italy, Japan and the US. Compared to China and the US, the UK has far fewer researchers, but it is far more efficient in terms of output per researcher due to mobility. One possible explanation for the better mobility of UK academics may be the global affiliation established by Great Britain since the colonial period, while the fact that the English language is used as a lingua franca may also be significant (Plume, 2012). This is further enriched by broader international research collaboration, which takes place across multiple institutions, borders, continents and time zones (Elsevier, 2016). The UK has performed better than other countries in terms of research output, knowledge transfer, human capital and productivity. The study also verified that the UK is a leading research hub in terms of the two quality indicators: usage and citation of articles (Plume, 2012). The 2016 Elsevier report, compiled for the UK's Department for Business, Energy \& Industrial Strategy (BEIS), summarised the UK's research performance as follows: 
The UK is a well-rounded research nation, with activity (as indicated by article outputs) across all major research fields. Its field-weighted citation impact (FWCI) is well above the world average and it continues to rank first amongst the comparator countries. (Elsevier, 2016, pp. 4-5)

Considering "brain circulation" between countries and sectors, it has been found that most internationally mobile academic professionals are involved in Knowledge and Technology Transfer (KTT) and impact the pedagogical paradigms of institutions in both the host and home country (Edler et al., 2011). Kim and Brooks (2012) have added the "Mode-3" research type to the Mode-1 and Mode-2 research typology of Gibbons et al. (1994). Mode-3 knowledge, according to Kim and Brooks (2012), is based on the biographical narratives of mobile academics' self-accounts of knowledge creation. This kind of "knowledge" was initially called "Transnational Identity Capital" (Kim, 2010). According to Kim (2010), Mode-1 is based on knowledge capital and the direction of knowledge movement, with the modality of knowledge creation being hierarchical, whereas Mode-2 knowledge incorporates social capital and has an interactive direction, with multiple nodes of knowledge creation. Mode3 has entwined circular movements of knowledge in the process of new knowledge creation. In their analysis of the biographical narratives of transnational mobile academics, Kim and Brooks (2012) argue that spatial transfer of knowledge, through academic mobility, is followed by knowledge transformation into "transnational identity capital"; it is embedded and travelled knowledge, which is not just Wissenschaft (scientific knowledge) but Weltanschauung (a view of the world). From this perspective, Kim and Brooks (2012) claim that "academic mobility is not a simple zero-sum game of brain drain/brain gains; but mobility leads to brain transfer and brain transformation" (Kim \& Brooks, 2012, p. 5).

Knowledge transfer is not, however, without drawbacks and challenges (Lola, 2005). The knowledge transferred from the West is highly competitive and largely unsympathetic to non-Western concerns, missions and priorities of research and development. For example, Western academic cultures make publication more complicated for non-Western academics by intensifying the competition from abroad and making local or regional publication less prestigious (Lola, 2005); emerging academic centres of excellence in Japan, Taiwan, Singapore and South Africa, for instance, are considered peripheral. China has only recently emerged as a focus of concern. The most prestigious journals and publishers are in the West and publish in English. This persuades non-Western academics to look towards the models and interests of the West. Journals in English exist in most countries of Africa, as well as in Taiwan, Japan and, of 
course, Hong Kong and Singapore. Even China now publishes scientific journals in English (Altbach, 2006).

The mobility of the academic profession has commodified knowledge, as well. Particularly teachers and researchers, who have become active actors in international teaching and research, are the major agents in the commodification of knowledge. Knowledge is becoming "exteriorised" from its creators (Meek, 2003); an essential difference has developed between "science as a search for truth" and "science as a search for a response to economic and political interests" (Oliveira, 2002, p. 1). Knowledge is produced not for its own sake, but in order to be sold and consumed, and to be priced or valorised in new production. Due to these new features, knowledge has become a major factor in the global competition for power. On a global scale, wealth and prosperity depends more on access to knowledge than access to natural resources. Meek (2003) goes on to explain that the development of the knowledge society has permeated the intrusion of market relations into many social institutions, including higher education, which have entered into competition. His explanation reads partly as follows:

As the knowledge society continues to develop, market relations based on knowledge production increasingly permeate all aspects and institutions of society, and the university is faced with a growing number of competitors in both research and training. Also, the commodification of knowledge is impacting heavily on the internal social structure of the scientific community. What is at question is the continuing importance and centrality of the university as knowledge is increasingly brought within market and political exchanges. (Meek, 2003, p. 3)

\section{Institutional Affiliation}

Recent changes, such as the reduction of research funding, the introduction of marketisation and New Public Management, and the massification of higher education, have gradually affected the nature of the relationship between academics and their institutions, as well as impacting their institutional commitment (Ball, 2012; Dill, 2002). The altruistic role of serving one's own society's central and ethical interests at large, and the important attachment that binds academics and institutions together, have dwindled significantly (Coady, 2000). Musselin (2007) articulated this as follows:

The university is no longer a place welcoming and sheltering academic activities, it has more and more taken over the role of an employer. The 
affiliation to one's institution is progressively transformed into work relationships. The responsibilities and duties of each academic are not only defined by his/her professional group but also by his/her institutional work arrangements. (Musselin, 2007, p. 180)

This situation has been further aggravated by the internationalisation of the academic profession. Academics are forced to be nomadic in their academic career. They migrate for research collaboration, in search of greener pastures than those of the peripheries, in order to enrich their academic credentials and upgrade their curriculum vitae, as well as for additional revenue. In some disciplines, academic mobility has made professors nomadic; they are detached from their families and from fulfilling domestic academic responsibilities. More and more academics, especially those from the periphery, remain in central higher education institutions long term, sometimes never returning; boundary crossing and making alternative use of cultural spaces in other well-structured higher education institutions has become common for many academics. All of these features have eroded commitment and the relationship between academics and their higher education institutions.

According to Hasegawa and Ogata (2009), one area in which institutional affiliation can be eroded is research. Academics need to travel in order to form scholarly networks and to exchange scientific knowledge (Gärdebo \& Soldal, 2017; Jöns, 2008). Research activities are often conveyed outside the premises of one's own institution and transferred into a foreign language, especially English. International collaborative research has become common practice due to opportunities established via the process of academic mobility. The 1992 "Carnegie Study" and the 2007 study "Changing Academic Profession" (CAP) confirm the decline of the sense of academics' belongingness to their respective institutions, demonstrating that institutional affiliations in general have declined by nearly 10 percentage points, from 31.2 percent in 1992 to 22.9 percent in 2007 (Hasegawa \& Ogata, 2009; Huang, 2009, 2013).

A further weakening of the relationship between academics and academic institutions is observed in language commitment in publication, research and teaching. The academic research community, particularly the international community, has largely engaged in collaborative research in English, which has become increasingly established as the lingua franca in many higher education domains, such as in instructional media and as the language of research and conferences. The most mobile academics teach in English, undertake research in English and present conference papers in English, both abroad and at home. The IAU (2010) has found that the English language is in high demand and is 
a priority among foreign students and scholars. Some 56 percent of respondents to the Third Global Survey of the International Association of Universities confirmed that English is the most highly demanded language 4 in their higher education institutions (IAU, 2010, p. 123). This encourages some academics to travel for collaborative research, or to improve their English through teaching and conference participation. For instance, Huang (2009) confirmed that mobile Japanese faculty members published more articles or books abroad in 2007 than in 1992, with their rate of publication growing from an average of 1.68 times (1992) to 2.28 times (2007). Japanese academics also wrote more articles or books in a foreign language (mainly English), with the average rising from 3.89 to 5.93 times. In South Africa, the number of international academics' publishing articles and books in another country and in a foreign language increased by 3.75 times in the period 1998-2000 (it increased by 3.67 times in the period 1991-2000) (Huang, 2009; Teichler, 2009; Wolhuter \& Higgs, 2004).

Publishing in English is becoming more rewarding than publishing in a local language. The hegemony of English-speaking systems in the academic world provides a forceful reason for academics from non-English speaking countries to abandon writing and publishing in indigenous languages. In Norway, for instance, "Academics are given 1000 Norwegian kroner for publishing an article in a Norwegian journal; they are given 7000 kroner for publishing an article in English outside Norway" (Lynch, 2006, p. 9).

The "Englishisation" of research, publication and instruction has grown and become common practice in Europe, Asia and Africa (Altbach \& Knight, 2007; Deem et al., 2008; Phillipson, 2008; Yang, 2002). This tendency has the far-reaching impact of marginalising immobile academics and local studies. Some prestigious international academics, particularly in developing countries, impact the research endeavours of local academics and home institutions by intensifying competition and redirecting the research paradigm to their own priority and language interests (Deem et al., 2008). This situation further reduces the dwindling commitment of academics to their institution.

\section{“Transnational Identity Capital” or Learning Experiences}

Academic mobility does, however, also result in intercultural learning and sensitivity (Krstic, 2012). It offers academics certain non-pecuniary benefits, such as increased access to professional development and greater

4 The second and the third were Spanish and French, accounting for only 10 and 8 percent of the respondents, respectively. 
international connections, as well as a range of personal benefits collectively known as "transnational identity capital" or learning experiences and skills that enable academics to engage with others (Balasooriya et al., 2014). Hamza (2010) asserts that the exposure of academics to foreign higher education institutions enables them to experience new things as they attempt to interact with local staff and classrooms. International academics bring home the new knowledge, perspectives, skills or practices that they acquire abroad. Although this may have short-term social and economic benefits, in the long term it can lead to the dilution or loss of the cultural characteristics of the indigenous culture, with the extension of "globalised" cultures and an increasing challenge to domestic cultures (Lumby \& Foskett, 2016).

According to Hamza (2010), three main themes of change and experience may arise as a result of international interaction: changes in personal and professional attitudes, understanding international students' learning styles and behaviour, and broadening global perspectives. Professional transformative learning and experience involve significant changes in understanding people and interpreting some significant aspect of the world. Teaching and communicating with students from different cultures creates challenges for faculty members in the classroom. At the same time, it develops the participants' professional skills in teaching in diverse classrooms and helps faculty members to acquire the ability to deal more effectively with international students and new expectations (Hamza, 2010). The experiences of academics in foreign universities "hold promise for informing fellow academics working in their home universities as they attempt to come to grips with the internationalization of their classroom" (Bodycott \& Walker, 2000, p. 80). Academics' new knowledge of local and global issues leads them to develop openness and new perspectives with regard to other people, cultures and global events (Hamza, 2010). In this regard, it is worth quoting some opinions of the international academic staff interviewed by Hamza (2010).

As far as I am concerned, travel in general opened up a whole new possibility of learning, in a way the books and research, and the internet really can't do. To actually have contact with people from other cultures, from other places, I think it is extraordinarily important ... my experience increased my tolerance. Knowledge of another people, another way of life, and another culture provides greater understanding, thus greater tolerance. I believe if everyone could have an experience like mine, the world would be a more peaceful place. (Hamza, 2010, p. 62) 
International academics also bring many international perspectives home and enlighten those academic staff and students who never travel abroad. This is the other face of "internationalisation at home". Hamza (2010) quotes two of his other interviewees, both of whom have worked in the Arab world:

Coming back to the U.S., I have a different view of the world, which I can bring to the table here to help educate people about Arab countries and about international issues (Angela). I prepared the curriculum, so I brought to the curriculum my experience of teaching overseas for sure. I am encouraging my own three daughters who are in college now and whenever I have the opportunity, I advise students, young people, and their friends to go abroad (Carol). (Hamza, 2010, p. 64)

International academics also face challenges in teaching foreign students abroad from a pedagogical perspective. According to Trent (2012) and Edwards and Usher (2008), for example, the International English-Language Teaching Assistant (IELTA) 5 programme in Hong Kong, in addition to helping participants develop their cultural awareness and their skills as teachers and learners, has led to unintended results, such as marginalisation. This is manifested through students quitting language classes, and through "othering" or the "us and them" categorisation. Students quit IELTA classes because the international scholars teach differently from the learning traditions and experiences of Hong Kong students. According to one IELTA, Hong Kong students

are really burdened by exams and are really dependent on the teacher. The classes have a huge emphasis on students being passive, taking notes and memorization based learning, not questioning information, which I think is part of their background in schools; in Hong Kong I understand schools are very teacher dominated. And this is very different than my experience in New Zealand universities. Over there, there is definitely a lot more emphasis on independent learning, class discussions and debates, and students' critical responses to what they are taught. (Trent, 2012, p. 59)

In some countries, the importing of foreign academics reduces the morale of native academics. Better pay and more privileges for similarly qualified

5 "The IELTA program, which recruits up to a dozen teaching assistants per year from Western and Asian Countries, represents part of the university's strategic plan for internationalisation by fostering a global perspective among staff and students through the provision of national and international teaching and learning experiences" (Trent, 2012, pp. 54-55). 
foreign staff affects the situation at home (Rivers, 2010). As the author observes, an instrumental case is represented by Ethiopian higher education institutions, where Indian academic staff are better paid than local staff. This has led to dissatisfaction among local staff, which in turn erodes institutional commitment.

International academics sometimes bridge foreign and home institutions in some ways, and the effects are both rewarding and challenging. International or mobile scholars suffer from the difficulties of reconciling/harmonising the domestic situation with new foreign academic experiences, which eventually affects the overall academic performance at home. This is particularly severe in developing countries. It is further intensified by so-called Diaspora scholars, who have studied and lived in the Global North and represent a significant factor in complicating the academic culture in the developing world. Diaspora scholars can be considered to be agents of brain circulation between centres and peripheries. If not properly managed, they pose additional challenges, as they are well acquainted with the academic and socioeconomic cultures of the country in which they lived. Altbach advocates making better use of the Diaspora, whose conflicting impact can be significant and complex. On the other hand, he claims that academic conflict between foreign educated academics and their local educated colleagues has gradually affected overall academic performance at home. In spite of this conflicting approach, Altbach (2007) unambiguously elucidates the challenges facing the interaction between foreign educated academics and their locally educated colleagues as follows:

In many developing countries, academics with foreign degrees constitute a significant part of the professoriate. Furthermore, these returnees are clustered at the top of the profession and dominate the research-oriented universities. They are the 'power elite' of the academic community. ... Scholars returning from abroad often wish to employ the values they absorbed during their studies to upgrade local standards, whether or not such replication is practical or desirable in local conditions. These academics follow the latest international academic developments and seek to maintain links with the countries in which they studied, often importing scientific equipment as well as ideas. Conflicts between foreignreturned academics and their locally educated colleagues are common. (Altbach, 2007, p. 143)

Mobile academics therefore need to be adequately prepared for internationalisation and for different academic and cultural encounters, such as a diverse student population, various academic cultures and sets of knowledge 
bases, and different learning styles. This is because education today requires doing "different things in different ways rather than doing the same things in different ways" (Dale, 2005, p. 117). Academic staff engaged in international teaching require additional "skills to teach" in order to ensure global adaptability and "legitimate peripheral participation" (Pherali, 2012).

\section{Academic Status and Profile}

The marketisation of higher education has been closely linked to neoliberal philosophy, globalisation, the emergence of the knowledge economy, and internationalisation. Market mechanisms and principles affect the teaching and research tasks and the status and profile of the academic profession at home and abroad (Naidoo, 2005), triggering competitive academic mobility and employability. The traditional employment security of the academic profession is weakened by mobile academics and contractual employment of part-timers and casual academics. Inter alia, universities have been persuaded into a new division of academic labour and severe competition for external research funding and international recruitment of research staff (Kim \& Brooks, 2012). Market mechanisms have also introduced such practices as casualisation of academic labour, end of tenure, and the need for new forms of governance and management, while entrepreneurial management skills are increasingly becoming "transnational" and "transferable".

Academic mobility has given rise to phenomena that have made the academic market more open. As part of a major university reform, the United Kingdom abolished academic tenure to make the entire academic system more competitive and international. In Germany, many academics are forced to compete for new positions at other universities, as most new academic appointments do not allow promotion (Kim \& Brooks, 2012). In Central Europe and the countries of the former Soviet Union, the traditional academic profession has been greatly weakened by changes in working conditions, deteriorating salaries, competitiveness and the resultant loss of status (Altbach, 2006; Henkel, 2007). Some of the most prestigious universities in the UK, such as Oxford, Cambridge, the London School of Economics, St Andrews and the Open University, have recruited vice-chancellors from abroad, notably from New Zealand, Australia, USA and South Africa. In short, the emergence of manager-academics in entrepreneurial research universities has become a global phenomenon (Kim \& Brooks, 2012; Musselin, 2007).

This general transformation of higher education has been further enhanced by the transnational mobility of academics. In the process of mobility 
and employability, academics lose their academic autonomy and professional power and generally turn into "skilled entrepreneurs" (Olssen, 2002). Academics are expected to compete in the "academic marketplace" by deliberately designing attractive and competitive courses at home and abroad. As a result, the intellectual merit of the programme is pitted against the need to dumb down standards and make courses appealing for the requirements of the market (Olssen, 2002). Subsequently, the traditional societal respect, academic values and prestige of the academic profession are deteriorating and academics are becoming increasingly commodified (Stilwell, 2003) to be sold abroad. This altered status, profile and role makes academics victims of change rather than agents of change (Doring, 2002). The new role and work transform academics and their profession into "hegemonic tools" that reproduce dominant ideologies, rather than making them "counter-hegemonic agents" who challenge dominant ideologies and promote diversity (Morley, 2003). Consequently, academic conservatism and the changed role of the academic profession coexist in conflict (Enders, 2007; Kehm \& Teichler, 2013; Power, 1994; Strathern, 2000).

According to UNESCO (2006), academic accountability has become the norm for the new academic environment, requiring academics to increase productivity with less financial expenditure. Academic accountability also includes issues such as academic governmentality by rules and regulations, as well as rigorous assessment procedures. Furthermore, it forces academics to raise funds and commercialise their research output in various ways. One major way of conforming to the new changes is transnational academic mobility in order to commercialise knowledge and raise funds. The development of market-oriented principles and practices in higher education institutions has compelled academics to behave like entrepreneurs, marketing their expertise, services and research findings locally and abroad. As a result, issues of higher education have become not only the concern of education ministries but also of ministries of commerce and human resource development (Deccan Herald News, 2015). De Wit and Altbach (2015) observed these features of higher education at the conference of the Association of International Educators (NAFSA) held in Boston, USA, on 24-29 May 2015, with over 11,00o participants from 100 countries in attendance. Unlike any time before, the conference brought together a broad range of agents, including recruitment agents, information technology services, insurance companies, marketing companies, security risk management, telecommunications, testing services, travel companies, visa expediters, language learning programmes and credential evaluators (de Wit \& Altbach, 2015).

The commodification of academics is considered by some as an assault on the academic profession. In defence of the autonomy of professions against 
vested market and managerial interests, Freidson (2007) argues that these managerial strategies should be resisted, as they impoverish the public domain of knowledge and skill that was previously available for free. The various transformative factors have changed and challenged the professional identity, specialisation, expectations and work roles of academics, as well as their commitment (Kogan \& Teichler, 2007). British sociologist Basil Bernstein (1996) perceived the academic crisis in terms of the development of a new and secular concept of knowledge, whereby knowledge is divorced from its creators:

There is a new concept of knowledge and of its relation to those who create and use it. This new concept is a truly secular concept. Knowledge should flow like money to wherever it can create advantage and profit. Indeed knowledge is not like money, it is money. Knowledge is divorced from persons, their commitments, their personal dedications. ... Knowledge, after nearly a thousand years, is divorced from inwardness and literally dehumanized ... what is at stake is the very concept of education itself. (Bernstein, 1996, pp. 87-88)

As some scholars from more restrictive countries enjoy more academic freedom, the academic freedom of others has been restricted and limited. Some countries have placed restrictions on what can be researched and what the academic community can relay to the public (Deccan Herald News, 2015), thus limiting the academic freedom of research and community services. This situation has resulted in the "nationalisation of internationalisation" (de Wit \& Altbach, 2015). The University of California at Berkeley, for example, plans to open a global campus ten miles from Berkeley's main campus at Richmond Bay. This is an unusual plan in an era in which many higher education institutions from the US, the UK, Australia, Singapore, South Africa and so on are establishing branch campuses abroad. The new campus will offer a "global citizenship" curriculum. In opening a global campus near the home campus, the intention of the University of California is "to establish partnerships with universities from around the world while preserving full academic freedom for its faculty” (Will, 2015).

\section{Conclusion}

Inter alia, globalisation has contributed to the transformation of higher education, the academic profession, and the process of knowledge production. The academic profession and academic faculty members are pivotal actors in the process of change in higher education. 
Since the 1990s, the new internationalisation of higher education and the academic profession has become a widespread and active process and strategy. The universality of knowledge and knowledge creation, its entrepreneurial importance, and the emergence of the knowledge economy and society have influenced the mobility of the academic profession. The transnational mobility of academics has increased significantly in the twenty-first century as a result of changes in higher education and the academic profession, and an intensification of international competition between universities for skilled researchers and revenue. Although there are many actors initiating and enhancing the process of internationalisation, the academic profession is the key actor in this regard. It has initiated contemporary transnational academic mobility and impacted academics in various ways. Academic staff perform competitive international teaching and research, which are the main features of internationalisation. Transnational academic mobility has affected academics and the profession on individual, institutional and/or global levels.

In the process of internationalisation operating under neoliberal, market and managerial principles, the academic profession both benefits and faces challenges. Mobile academics broaden their global perspectives and learn to deal with diverse schools of thought and academic cultures. This will likely enable academics to pursue new and unexplored research topics, and intensify the transfer, production and commodification of knowledge, making them more like entrepreneurs. International academic staff earn non-pecuniary benefits, collectively known as "transnational identity capital" and skills, including increased access to professional development and greater international connections. They may also acquire transformative learning. Academics try to accommodate a student population with a diverse background, enabling them to learn to teach in an international setting. They can also bring home new professional and academic experiences, incorporate new knowledge, perspectives and skills, and broaden their world outlook. The changes and the experiences academics are exposed to can result in changes in personal and professional attitudes.

International academics face the challenge of integrating themselves into a new academic and social environment. In a way, they remain foreign. Some academic staff exploit foreignness as an opportunity to a new breakthrough and paradigm shift in knowledge creation. Audit systems, collaborative research outside one's own higher education institution, publication abroad, the use of a foreign language for publication and so on have eroded the institutional affiliation of academic staff to a varying degree. The policy of brain gain by some developed countries of the world, and the increasing need of developing countries for capacity-building through the process of internationalisation, have initiated 
a brain drain and imbalanced internationalisation, perpetuating the unequal development situation in the world. In their cultural learning, academics who stay abroad for longer periods may suffer from cultural shock and the dilution or loss of the cultural characteristics of their original culture.

The sum total of these changes, experiences and challenges affects the status and profile of academics and the academic profession in general. Changes in higher education, the internationalisation of the academic profession, and the subsequent beneficial and challenging impacts have diminished the traditional prestige, status, autonomy and profile of academics and the academic profession.

In order to utilise opportunities and to ease challenges, international academics need to be well prepared psychologically, pedagogically, technically and socially. They need relevant language skills, preferably in English, and training on how to operate information and communication technology facilities. Moreover, they need advance knowledge of the academic, pedagogical, social and cultural environment of their destination.

\section{References}

Alemu, S. K. (2016). Conceptualizing internationalization of higher education and the academic profession with a comparative analysis of Europe, Asia-Pacific, and Africa (Doctoral Dissertation). University of Ljubljana, Faculty of Education.

Altbach, P. G. (2006). International higher education: Reflection on policy and practice. Centre for International Higher Education.

Altbach, P. G. (2007). Tradition and transition: The international imperative in higher education. Centre for International Higher Education.

Altbach, P. G., \& Knight, J. (2007). The internationalization of higher education: motivation and realities. Journal of Studies in International Education, 11(3-4), 290-305.

Balasooriya, C., Asante, A., Jayasinha, R., \& Razee, H. (2014). Academic mobility and migration: reflection of international academics in Australia. In N. Maadad \& M. Tight (Eds), Academic Mobility, (pp.1 17-135). Emerald Group Publishing.

Ball, S. (2012). Performativity, commodification and commitment: An I-spy guide to the neoliberal university. British Journal of Educational Studies 6oth Anniversary Special Issue, 6o(1), 17-28.

Becher, T., \& Trowler, P. (2001). Academic tribes and territories: Intellectual enquiry and the culture of disciplines. The Society for research into higher education and Open University press.

Bedenlier, S., \& Zawacki-Richter, O. (2015). Internationalization of higher education and the impacts on academic faculty members. Research in Comparative and International Education, 10(2), 185-201. Sage publication.

Bernstein, B. (1996). Pedagogy, symbolic control and identity: Theory, research and critique. Taylor and 
Francis.

Bodycott, P., \& Walker, A. (200o). Teaching abroad: Lessons learned about inter-cultural understanding for teachers in higher education. Teaching in Higher Education, 5(1), 79-94.

Clark, B. R. (1987). The academic life: Small worlds, different worlds. Carnegie Foundation for the Advancement of Teaching.

Coady, T. (2000). Universities and the ideals of inquiry. In T. Coady (Ed.), Why universities matter: A conversation about values, means and directions (pp. 3-25). Allen \& Unwin.

Dale, R. (2005). Globalization, knowledge economy and comparative education. Comparative Education, 41(2), 117-149.

de Wit, H., \& Altbach, P. G. (2015, June 12). The nationalization of internationalization. Issue No. 371. https://www.universityworldnews.com/post.php?story=20150609123816285

Deccan, H. (2015, August 21). Government keen on 'exporting' higher education. http://www. deccanherald.com/content/496416/govt-keen-exporting-higher-education.html Deem, R., Mok, K. H., \& Lucas, L. (2008). Transforming higher education in whose image? Exploring the concept of the 'world-class' university in Europe and Asia. Higher Education Policy, 21, $83-97$.

Dill, D. (2002, September 5-7). Regulatory success, regulatory failure: A review of the regulation of academic quality in the United Kingdom. Paper presented at the Consortium of Higher Education Researchers (CHER) Annual Research Conference, Vienna, Austria.

Doring, A. (2002) Challenges to the academic role of change agent. Journal of Further and Higher Education, 26(2), 139-148.

Edler, J., Fier, H., \& Grimpe, C. (2011). International scientist mobility and the locus of knowledge and technology transfer. Research Policy, 40(6), 791-805.

Edwards, R., \& Usher, R. (2008). Globalization and pedagogy: Space, place and identity. Routledge. Elsevier (2016). International comparative performance of the UK research base 2016. A report prepared by Elsevier for the UK's Department for Business, Energy \& Industrial Strategy. https:// assets.publishing.service.gov.uk/government/uploads/system/uploads/attachment_data/file/66o855/ uk-research-base-international-comparison-2016.pdf

Enders, J. (2007) The academic profession. In J. Forest, \& P. Altbach (Eds.), International handbook of higher education (pp. 5-21). Springer.

Freidson, E. (2007). Professionalism: The third logic. Polity Press.

Gärdebo, J., \& Soldal, K. (Eds.). (2017). The travelling scientist's itinerary. US-AB.

Gibbons, M., Limoges, C., Nowotny, H., Schwartzman, S., Scott, P., \& Trow, M. (1994). The new production of knowledge: The dynamics of science and research in contemporary societies. Sage Publications.

Hamza, A. (2010). International experience: An opportunity for professional development in higher education. Journal of Studies in International Education, 14(1), 50-69.

Hasegawa, Y., \& Ogata, N. (2009). Japan. The changing academic profession in Japan. In The changing academic profession over 1992-2007: International, comparative, and qualitative perspectives 
(pp. 271-287). Hiroshima University.

Henkel, M. (2007). Shifting boundaries and the academic profession. In Kogan, M., \& U. Teichler (Eds.), Key challenges to the academic profession (pp. 191-204). International Centre for Higher Education Research Kassel (INCHER) \& Paris: UNESCO Forum on Higher Education Research and Knowledge.

Hopkins, J. (2013, November 15). Tracking transnational academic mobility down under. University World News, issue 296.

Huang, F. (2009). The internationalization of Japan's academic profession 1992-2007: Facts and views. In The changing academic profession over 1992-2007: International, comparative, and qualitative perspectives (pp. 97-111). Hiroshima University.

Huang, F. (2013). The internationalization of the academic profession. In F. Huang, M. J. Finkelstein, \& M. Rostan (Eds.), The internationalization of the academy: Changes, realities and prospects (pp. 1-21). Springer.

Hugo, G. (2009). Issues and options for enhancing the international mobility of researchers. Omani Journal of Applied Sciences, 1(1), 9-53.

International University Association (IAU). (2010). Internationalization of higher education: Global trends, regional perspectives. IAU 3 rd Global Survey Report.

Jiang, X. (2008). Towards the internationalization of higher education from a critical perspective. Journal of Further and Higher Education, 32(4), 347-358.

Jöns, H. (2008). Academic travel from Cambridge University and the formation of centres of knowledge, 1885-1954. Journal of Historical Geography, 34(2), 338-362.

Kehm, B. M., \& Teichler, U. (2013). Introduction. In B. M. Kehm, \& U.Teichler (Eds.), The academic profession in Europe: New tasks and new challenges (pp. 1-6). Springer.

Kim, T. (2010). Transnational academic mobility, knowledge, and identity capital. Discourse: Studies in the Cultural Politics of Education, 31(5), 577-591.

Kim, T., \& Brooks, R. (2012). Internationalization, mobile academics, and knowledge creation in universities: A comparative analysis. Society for research into higher education.

Knight, J. (1996). Internationalization at Canadian universities: The changing landscape. Association of Universities and Colleges in Canada (AUCC).

Knight, J. (1999). Internationalization of higher education. In J. Knight \& H. de Wit (Eds.), Quality and internationalization of higher education (pp. 13-28). IMHE/OECD.

Knight, J. (2004). Internationalization remodelled: Definition, approaches, and rationales. Journal of Studies in International Education, 8(1), 5-31.

Kogan, M., \& Teichler, U. (2007). Key challenges to the academic profession. UNESCO Forum on Higher Education Research and Knowledge.

Krstic, S. (2012). Internationalization and competitiveness of universities through different types of researchers' mobility-facing the future. In C., Adrian, P. Scott, L. V., L. Wilson (Eds.), European higher education at crossroads. Between the Bologna Process and national reforms, part 1 (pp. 511-524). Springer. 
Lola, M. (2005). Researchers' mobility: Opportunities and challenges. In T. Gabaldon et al. (Eds.), Career paths and mobility of researchers in Europe: Proceedings of the conference ESRM2OO4 and the MCFA at ESOF2004 (pp. 21-28). Cuvillier Verlag.

Lumby, J., \& Foskett, N. (2016). Internationalisation and culture in higher education. Educational Management Administration and Leadership, 44(1), 95-111.

Lynch, K. (2006). Neo-Libralism and marketisation: The implications for higher education. European Educational Research Journal, 5(1), 1-17.

Meek, V. L. (2003). Market coordination, research management and the future of higher education in the post-industrial era. UNESCO Forum Regional Scientific Committee for Asia and the Pacific. Moraru, L., Praister, M., Marin, S. A., \& Bentea, C. C. (2013). The academic profession: Quality assurance, governance, relevance, and satisfaction. In B. Barbara, M. Kehm, \& U. Teichler (Eds), The academic profession in Europe: New tasks and new challenges (pp. 141-162). Springer.

Morley, L. (2003). Quality and power in higher education. Society for Research into Higher Education (SRHE) and Open University Press.

Musselin, C. (2007). Transformation of academic work: Facts and analysis. In M. Kogan \& U. Teichler (Eds.), Key challenges to the academic profession (pp. 175-190). International Centre for Higher Education Research Kassel (INCHER) \& Paris: UNESCO Forum on Higher Education Research and Knowledge.

Naidoo, R. (2005). Universities in the marketplace: The distortion of teaching and research. In R. Barnett (Ed.), Reshaping the University: New relationships between research, scholarship and teaching (pp. 27-36). Open University Press.

Oliveira, L. (2002). Commodification of science and paradoxes in universities. ISCTE, University of Lisbon. http://rektorat.unizg.hr/rk/Docs/uisa.html

Olssen, M. (2002). The restructuring of tertiary education in New Zealand: Governmentality, neoliberalism, democracy. McGill Journal of Education, 37(1), 57-88.

Pedró, F. (2009). Continuity and change in the academic profession in European countries. Higher Education in Europe, 34(3-4), 411-429.

Pherali, T. J. (2012). Academic mobility, language, and cultural capital: The experience of transnational academics in British higher education institutions. Journal of Studies in International Education, 16(4), 313-333.

Phillipson, R. (2008). English, panacea or pandemic? Keynote lecture, at the international conference on language issues in English-Medium universities: A global concern. https://www.fe.hku.hk/clear/ conferenceo8/index.html

Phipps, A. (2005). Making academics: Work in progress. In R. Barnett (Ed.), Reshaping the University: New relationships between research, scholarship and teaching (pp. 136-150). Open University.

Plume, A. (2012). UK study reveals that international researchers are significantly more productive.

The Academic Executive Brief, Brain Circulation, 2(1), 42-59.

Power, M. (1994). The audit explosion. Demos. 
Rivers, D. (2010). Ideologies of internationalization and treatment of diversity within Japanese higher education. Journal of Higher Education Policy and Management, 32(5), 441-454.

Sandgren, D., Elig, N., Hovde, P., \& et al. (1999). How international experience affects teaching: Understanding the impact of faculty study abroad. Journal of Studies in International Education, 11(3-4), 359-372.

Stilwell, F. (2003). Higher education, commercial criteria and economic incentives. Journal of Higher Education Policy and Management, 25(2), 51-61.

Strathern, M. (Ed.) (200o). Audit cultures: Anthropological studies in accountability, ethics and the academy. Routledge.

Teichler, U. (2009). Internationalization of higher education: European experiences. Asia Pacific Education Review 10(1), 93-106.

Teichler, U., Arimoto, A., \& Cummings, W. (2013). The changing academic profession. Springer. Trent, J. (2012). The internationalization of tertiary education in Asia: Language, identity and conflict. Journal of Research in International Education, 11(1), 50-69.

United Nations Education, Scientific and Cultural Organization (UNESCO). (2006). Higher education in South-East Asia. UNESCO Bangkok.

Vabø, A. (2007). Challenges of internationalization for the academic profession in Norway. In M.

Kogan \& U. Teichler (Eds.), Key challenges to the academic profession (pp. 99-107). Jenior. Will, M. (2015, November 24). Berkeley plans to build a global campus, 10 miles from home. The Chronicle of Higher Education. http://chronicle.com/article/Berkeley-Plans-to-Build-a/151343 Wolhuter, C. C., \& Higgs, L. G. (2004). How internationalized is the South African academic profession In J. Van der Elst \& C. C.Wolhuter (Eds.), Internationalization and human resource development in the African Union: Challenges for the tertiary sector (pp. 262-271). Proceedings of the 7 th International Conference of IEASA. Noordbrug: The Platinum Press.

Yang, R. (2002). Third delight: The internationalization of higher education in China. Routledge. 


\section{Biographical note}

Sintayehu Kassaye Alemu, $\mathrm{PhD}$, is an associate professor in history at the Department of History and Heritage Management, College of Social Sciences and Languages, at Mekelle University, Ethiopia. His research interests include general education, higher education, internationalization of higher education, and modern Ethiopian history. 